\title{
Effect of treatment with methylprednisolone on duration of pseudopregnancy and on macrophages and $T$ lymphocytes in rabbit corpora lutea
}

\author{
S. J. Seiner, W. Schramm and P. L. Keyes* \\ Department of Physiology, and Reproductive Sciences Program, The University of Michigan, \\ Ann Arbor, MI 48109, USA
}

\begin{abstract}
Summary. The potential role of macrophages and $\mathrm{T}$ lymphocytes in the destruction of the corpus luteum at the end of the luteal phase was investigated by treating pseudopregnant rabbits with the immunosuppressant glucocorticoid methylprednisolone. Eleven specific pathogen-free New Zealand White rabbits were injected with pregnant mares' serum gonadotrophin (40 iu, i.m.), followed 2 days later by human chorionic gonadotrophin (40 iu, i.v.) to stimulate ovulation. The following day (day 1 of pseudopregnancy) all animals had an oestradiol-filled Silastic capsule implanted s.c., to ensure that oestradiol, the luteotrophic hormone in this species, would not be limiting. From day 10 of pseudopregnancy, three animals were injected with a low dose of methylprednisolone ( $2 \mathrm{mg} \mathrm{kg}^{-1}$ per day) until day 20 . Three other animals were injected with a higher dose of methylprednisolone $\left(20 \mathrm{mg} \mathrm{kg}^{-1}\right.$ per day) from day 13 of pseudopregnancy until day 19. Five animals served as control, vehicle-injected animals. Blood samples were taken at intervals and assayed for progesterone. Immunofluorescence was used to stain luteal tissue for macrophages, $T$ lymphocytes and class II antigens, and positive cells were counted under high-power magnification. Methylprednisolone treatment reduced (by about $70 \%$ ), but did not eliminate, the macrophages in the regressing corpora lutea. In contrast, the high dose of methylprednisolone essentially eliminated $T$ lymphocytes, and reduced (by about $90 \%$ ) the number of cells expressing class II antigen in the luteal tissue. Despite the effects of methylprednisolone on these cells, serum progesterone profiles were not altered by treatment with methylprednisolone, and pseudopregnancy was of normal duration. These results indicate that the methylprednisolone-induced reduction in numbers of luteal macrophages and $\mathrm{T}$ lymphocytes is compatible with a luteal phase of normal duration in rabbits.
\end{abstract}

KeyHords: methylprednisolone; pseudopregnancy; macrophages; T lymphocytes; rabbit

\section{Introduction}

The decline of luteal progesterone synthesis at the end of a non-fertile cycle has been attributed primarily to prostaglandin $\mathrm{F}_{2 \alpha}\left(\mathrm{PGF}_{2 \alpha}\right)$ (see review by Knickerbocker et al., 1988) acting directly on luteal cells (Fitz et al., 1982; Pate \& Nephew, 1988; Wiltbank et al., 1990). Prostaglandin $F_{2 \alpha}$ can promote the loss of steroidogenic capacity, but other systems are presumably responsible for the disposal of the waning corpus luteum. Bagavandoss et al. (1990) reported that the rabbit corpus luteum becomes rapidly infiltrated with macrophages within a few days at the end of the pseudopregnancy or after parturition. Lei et al. (1991) have reported macrophage infiltration of the

*Reprint requests. 
human corpus luteum in late luteal phase. T lymphocytes are present in the rabbit corpus luteum throughout the luteal phase (Bagavandoss et al., 1990) and gamma-interferon (IFN- $\gamma$ ), a cytokine produced by $\mathrm{T}$ lymphocytes, stimulates the expression of class II antigen and inhibits progesterone production in bovine luteal cells (Fairchild \& Pate, 1989, 1991). Although macrophages and T lymphocytes are present in the corpus luteum, the role of these cells in the termination of the luteal phase is unknown. We used the anti-inflammatory drug methylprednisolone to suppress macrophages and $\mathrm{T}$ lymphocytes to determine whether such immunosuppression would alter the luteal phase.

\section{Materials and Methods}

\section{Animals and treatments}

New Zealand White, pathogen-free rabbits, weighing approximately $3 \mathrm{~kg}$, were purchased from Hazleton (Denver, PA). The animals were kept in a room at $20-21^{\circ} \mathrm{C}$, and given water and rabbit chow ad libitum. Ovulation and pseudopregnancy were induced by intramuscular injection of 40 iu pregnant mares' serum gonadotrophin (Sigma, St Louis, MO), and two days later (day 0) by an intravenous injection of 40 iu human chorionic gonadotrophin (hCG) (Sigma). On day 1 of pseudopregnancy, a Silastic capsule filled with oestradiol was implanted subcutaneously in all of the animals to ensure that a low concentration of oestrogen, the luteotrophic hormone, would be present throughout the experiment. The characteristics of this implant have been described (Bill \& Keyes, 1983). Three animals were injected i.m. with methylprednisolone $\left(2 \mathrm{mg} \mathrm{kg}^{-1}\right.$ per day; three injections a day) from day 10 of pseudopregnancy until they were killed (overdose of sodium pentobarbital) on day 20 . Blood was taken from the marginal ear vein on days $0,3,6,9,10,12,14,16,18$ and 19 , and the serum was frozen for later assay of progesterone. Three animals were injected with a higher dose of methylprednisolone $\left(20 \mathrm{mg} \mathrm{kg}^{-1}\right.$ per day; two injections a day) starting on day 13 and ending on day 19 when the animals were killed. The period of treatment was shortened for the animals treated with the higher dose because of the possible effects on the health of the animals. Blood samples were taken on days $0,3,9,12,13,15,17,18$ and 19 and the serum was frozen. Five animals served as vehicle-injected control animals: two following the same protocol as animals treated with the lower dose, and three following the same protocol as animals treated with the higher dose.

\section{Immunofluorescence}

At the end of the experiments (day 19 or 20 of pseudopregnancy), several corpora lutea from each animal were dissected from the ovaries, and stored in liquid nitrogen. The corpora lutea were sectioned $(8 \mu \mathrm{m}$ sections) on a cryostat and stained for macrophages (Tsukada et al., 1986), T lymphocytes (Wilkinson et al., 1984), and class II antigen (Lobel \& Knight, 1984) using monoclonal antibodies and immunofluorescence as reported previously for rabbit luteal tissue (Bagavandoss et al., 1990). All samples were coded, and macrophage nuclei were counted in two to four randomly chosen $\times 480$ fields within each corpus luteum; at least two randomly selected corpora lutea were examined for each rabbit. T lymphocytes and cells expressing class II antigen were counted in a similar way in $\times 384$ fields.

\section{Progesterone radioimmunoassay}

Progesterone was measured in unextracted serum using a solid-phase radioimmunoassay kit (BioQuant, Ann Arbor MI). The characteristics of the assay have been reported (Foster et al., 1989). Samples assayed by liquid-phase radioimmunoassay and by the BioQuant Kit were in agreement $(r=0.987 ; P<0.0004)$. The intra-assay and interassay coefficients of variation for quality control sera containing 1.2 and $4.1 \mathrm{ng}$ progesterone $\mathrm{ml}^{-1}$ were $11.2 \%$ and $14.7 \%$, respectively (11 assays). Assay sensitivity, defined as $2 \mathrm{sD}$ from buffer controls, averaged $0.2 \mathrm{ng} \mathrm{ml}^{-1}$ for $25 \mu \mathrm{l}$ of unextracted serum. The range of the standard curve was 10-200 pg per well at $80-20 \%$ inhibition of the tracer.

An animal in oestrus that had not ovulated (no corpora lutea present) was injected with methylprednisolone ( $2 \mathrm{mg}$ $\mathrm{kg}^{-1}$ per day) at intervals of $8 \mathrm{~h}$ for 10 days. Blood samples were taken on days $0,1,2,3,5,7$ and 9 of treatment and assayed for progesterone. This was done to determine whether methylprednisolone treatment resulted in any detectable progesterone that might originate from a source other than corpora lutea or progesterone-like activity by crossreactivity with the drug.

\section{Statistical analysis}

The data were analysed by analysis of variance. Error bars represent the standard error of the mean. 


\section{Results}

\section{Effect of methylprednisolone on luteal macrophages and $\mathrm{T}$ lymphocytes}

Since the data from control animals could not be distinguished from one another, the data from the two groups were combined into a single group. Treatment with both doses of methylprednisolone resulted in a decreased number of macrophages in the corpora lutea $(P<0.005$, Fig. 1a); in the control animals, the luteal tissue was heavily infiltrated with macrophages, so that counting individual cells was difficult.
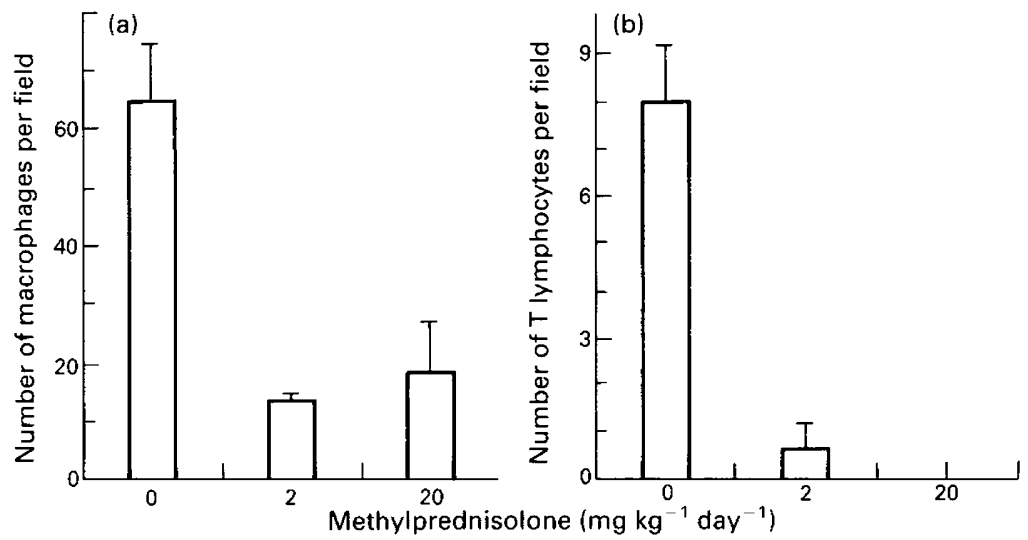

Fig. 1. Mean numbers of (a) macrophages $(\times 480$ field $)$ and (b) T lymphocytes $(\times 384$ field $)$ in the luteal tissue of control and methylprednisolone-treated rabbits. In this and subsequent figures, cells are enumerated in each animal by counting the nuclei of fluorescent cells in two to four randomly chosen fields within each corpus luteum in at least two separately stained tissues. Data are means \pm SEM, $n=5$ control animals (control animals from both experiments are combined); $n=3$ animals for each of the two methylprednisolone-treated groups.

Methylprednisolone treatment severely reduced $\mathrm{T}$ lymphocytes in the luteal tissue of the animals treated with both doses of the drug (Fig. $1 \mathrm{~b} ; P<0.0007)$; at the higher dose $\left(20 \mathrm{mg} \mathrm{kg}^{-1}\right.$ $\mathrm{day}^{-1}$ ) the corpora lutea were virtually devoid of $\mathrm{T}$ lymphocytes. The contrast between the luteal tissues of the controls and animals treated with the high dose can be seen (Fig. 2). T lymphocytes (the brightly stained cells) can be readily identified in the control (Fig. 2a), but were not observed in the luteal tissue of methylprednisolone-treated animals (Fig. 2b). Methylprednisolone treatment resulted in a decreased number of cells stained positively for class Il antigen (Fig. $3 ; P<0 \cdot 009$ ).

\section{Serum progesterone profiles}

In the non-ovulated rabbit treated with methylprednisolone, normal low serum progesterone $\left(<1 \mathrm{ng} \mathrm{ml}^{-1}\right)$ was found throughout the treatment period, and we therefore concluded that, in the absence of corpora lutea, treatment with this drug did not result in increased serum progesterone activity in this assay.

No differences were observed in mean values of serum progesterone for the two control groups; therefore, the animals were combined into a single control group. Methylprednisolone treatment did not affect either the concentration of serum progesterone or the duration of progesterone secretion, i.e. the duration of pseudopregnancy (Fig. 4). The mean luteal tissue weight ( \pm SEM) of the animals treated with the high dose of methylprednisolone $(8.1 \pm 2.7 \mathrm{mg}$ per corpus luteum) was not significantly different from that of the control animals $(7.7 \pm 0.6 \mathrm{mg}$ per corpus luteum). 
(a)

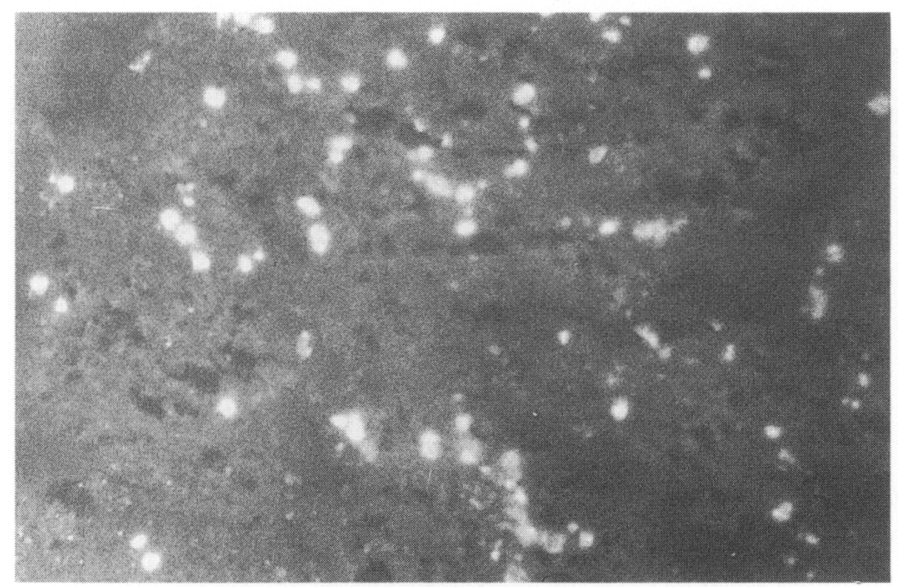

(b)

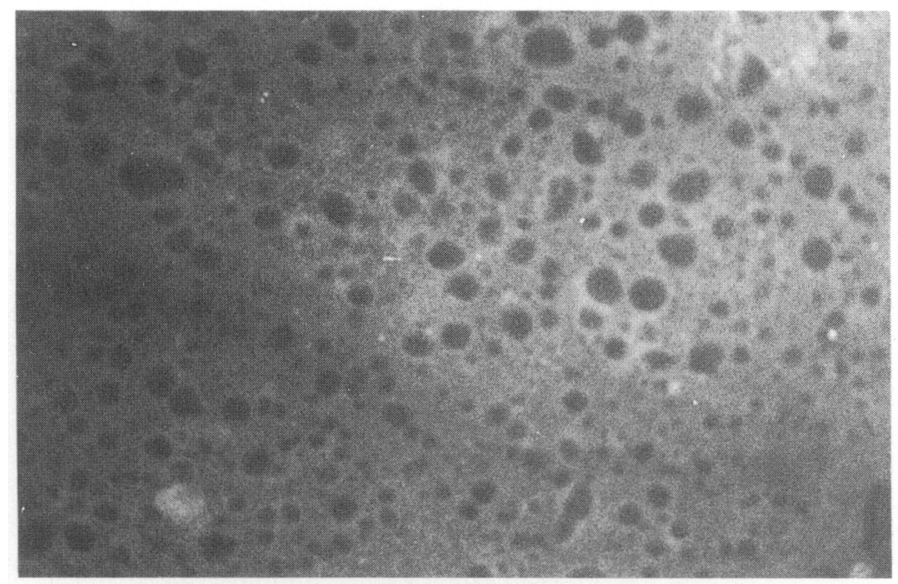

Fig. 2. Photomicrographs of luteal tissue with T lymphocytes stained by immunofluorescence: (a) control rabbit and (b) rabbit treated with $20 \mathrm{mg}$ methylprednisolone $\mathrm{kg}^{-1} \mathrm{day}^{-1}$. The brightly stained cells in the control tissue are $\mathrm{T}$ lymphocytes. The treated tissue is virtually devoid of T lymphocytes. $\times 384$.

\section{Discussion}

Glucocorticoid treatment has been shown to decrease numbers of circulating $T$ lymphocytes (Fauci et al., 1976) and T-lymphocyte proliferation (Gillis et al., 1979), and to inhibit macrophage functions and differentiation of monocytes into macrophages (Dimitriu, 1976; Fauci et al., 1976; Snyder \& Unanue, 1982; Baybutt \& Holsboer, 1990). Further, methylprednisolone has been used as an immunosuppressant in rabbits with renal allografts (Terada \& Ueno, 1984; Friedman 't al., 1973). In the present study, treatment with methylprednisolone reduced the number of macrophages detected by this monoclonal antibody, reduced the number of class-II-positive cells, and virtually eliminated $\mathrm{T}$ lymphocytes from the corpora lutea.

Despite reduced numbers of luteal macrophages and the severe depletion of luteal T lymphocytes in methylprednisolone-treated animals, neither serum progesterone concentrations nor the duration 


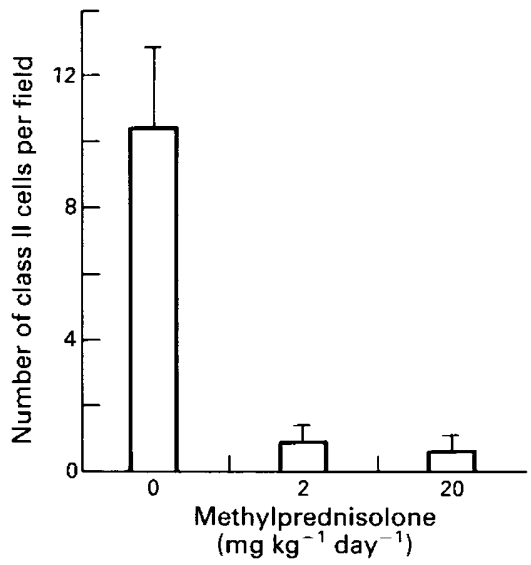

Fig. 3. Mean numbers of class-II-positive cells in the luteal tissue of control and methylprednisolonetreated rabbits $(\times 384$ field $)$.

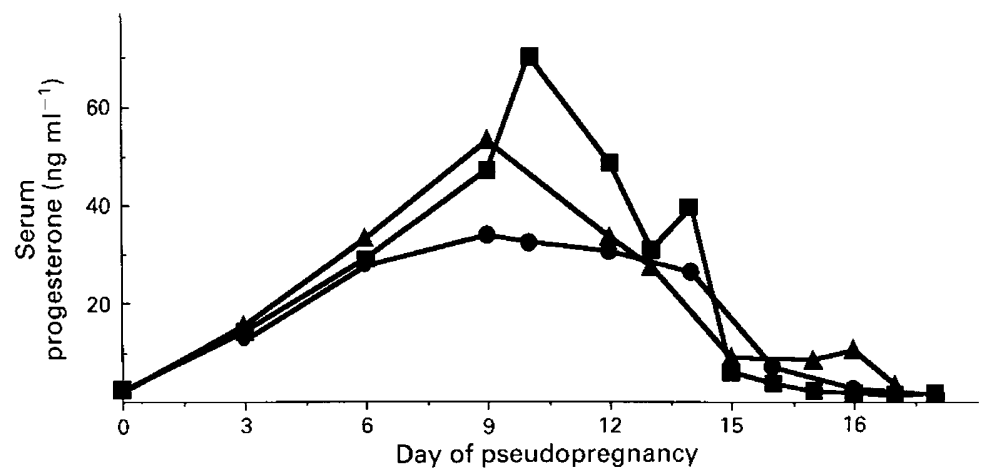

Fig. 4. Mean concentrations of serum progesterone of control rabbits $(n=5, \mathbf{\square})$ and rabbits treated with $2(\boldsymbol{\bullet})$ or $20(\boldsymbol{\Delta}) \mathrm{mg}$ methylprednisolone $\mathrm{kg}^{-1} \mathrm{day}^{-1}(n=3$, for each dose). Neither of the treated groups shows a significantly altered period of progesterone production; mean progesterone values are not significantly different among the three groups on any day of pseudopregnancy.

of progesterone secretion was noticeably affected. Pseudopregnancy in most domestic rabbits lasts about 16 to 18 days (Hilliard et al., 1974; Keyes et al., 1983) which is in agreement with our observations in both control and methylprednisolone-treated rabbits. Inspection of ovaries at the end of experiments revealed that, structurally, the corpora lutea were degenerating, indicating that physiological regression was occurring despite methylprednisolone treatment. The failure of the drug to alter pseudopregnancy must be viewed in the light of the fact that substantial numbers of macrophages remained in the corpora lutea. The macrophages may have been sufficient in numbers or activity to bring about involution of the corpora lutea. The doses of methylprednisolone used here are higher than the dose of methylprednisolone $\left(0.5 \mathrm{mg} \mathrm{kg}{ }^{-1} \mathrm{day}^{-1}\right)$ reported for rabbits with renal allografts (Friedman et al., 1973; Terada \& Ueno, 1984). It should be pointed out, however, that the latter rabbits were treated simultaneously with other immunosuppressants, such as azathioprine and cyclophosphamide, thus a comparison of methylprednisolone effectiveness cannot be made. Tomasgard (1976) reported that treatment of heifers with prednisolone, beginning 2 or 8 days after oestrus, reduced serum progesterone concentration, but did not appear to alter the histology of the corpus luteum. In a preliminary report (Wang et al., 1991), dexamethasone 
treatment prevented natural luteolysis in superovulated immature rats. The varied effects of these treatments in different species reflect both direct and indirect actions of the drug as well as the type and dose of drug used, and the time of onset and duration of drug treatment. Thus, the mechanism by which glucocorticoid alters luteal function cannot be identified at this time.

The effect of methylprednisolone on class II antigen expression might be related to the reduced numbers of $\mathrm{T}$ lymphocytes, which have been shown to be class II positive in rabbit luteal tissue (Bagavandoss et al., 1990). Fairchild \& Pate (1989) reported that IFN- $\gamma$ induces class II major histocompatibility complex antigens on cultured bovine luteal cells, suggesting that steroidogenic luteal cells may be involved in immune response mechanisms that are postulated to be associated with regression of the corpus luteum (Bagavandoss et al., 1988; Fairchild \& Pate, 1989).

The results of this study indicate that the immunosuppressive drug, methylprednisolone, when administered in high doses that reduced the numbers of macrophages and $\mathrm{T}$ lymphocytes in the corpus luteum, did not alter the luteal phase of the pseudopregnant rabbit.

Supported by NIH grants HD-07127 (PLK), 2-P30-HD-18258 (Morphology Core Facility), and a summer fellowship from The University of Michigan Medical School Student Biomedical Research Program.

\section{References}

Bagavandoss, P., Kunkel, S.L., Wiggins, R.C. \& Keyes, P.L. (1988) Tumor necrosis factor- $\alpha$ (TNF- $\alpha$ ) production and localization of macrophages and T lymphocytes in the rabbit corpus luteum. Endocrinology 122, 1185-1187.

Bagavandoss, P., Wiggins, R.C., Kunkel S.L., Remick, D.G. \& Keyes, P.L. (1990) Tumor necrosis factor production and accumulation of inflammatory cells in the corpus luteum of pseudopregnancy and pregnancy in rabbits. Biology of Reproduction 42, $367-376$.

Baybutt, H.N. \& Holsboer, F. (1990) Inhibition of macrophage differentiation and function by cortisol. Endocrinology 127, 476-480.

Bill, II, C.H. \& Keyes, P.L. (1983) 17 $\beta$-Estradiol maintains normal function of corpora lutea throughout pseudopregnancy in hypophysectomized rabbits. Biology of Reproduction 28, 608-617.

Dimitriu, A. (1976) Suppression of macrophage arming by corticosteroids. Cellular Immunology 21, 79-87.

Fairchild, D.L. \& Pate, J.L. (1989) Interferon-gamma induction of major histocompatibility complex antigens on cultured bovine luteal cells. Biology of Reproduction 40, 453-457.

Fairchild, D.L. \& Pate, J.L. (1991) Modulation of bovine luteal cell synthetic capacity by interferon-gamma. Biology of Reproduction 44, 357-363.

Fauci, A.S., Dale, D.C. \& Balow, J.E. (1976) Glucocorticosteroid therapy: mechanisms of action and clinical considerations. Annals of Internal Medicine 84, 304-315.

Fitz, T.A., Mayan, M.H., Sawyer, H.R. \& Niswender, G.D. (1982) Characterization of two steroidogenic cell types in the bovine corpus luteum. Biology of Reproduction 27, 703-711.

Foster, D.L., Ebling, F.J.P., Claypool, L.E., Wood, R.F., Adel, T.E. \& Schramm, W. (1989) Amplitude modulation of the nightly melatonin rise in the neonatal lamb and the subsequent timing of puberty. Biology of Reproduction 40, 920-928.
Friedman, E.A., Ueno, A., Beyer, M.M. \& Nicastri, A.D. (1973) Combination drug treatment in immunosuppression: effect of azathioprine, cyclophosphamide, and methylprednisolone on rabbit renal allografts. Transplantation 15, 619-623.

Gillis, S., Crabtree, G.R. \& Smith, K.A. (1979) Glucocorticoid-induced inhibition of $\mathrm{T}$ cell growth factor production: I. The effect on mitogen-induced lymphocyte proliferation. Journal of Immunology 123, 1624-1631.

Hilliard, J., Scaramuzzi, R.J., Penardi, R. \& Sawyer, C.H. (1974) Serum progesterone levels in hysterectomized, pseudopregnant rabbits. Proceedings of the Society for Experimental Biology and Medicine 145, 151-153.

Keyes, P.L., Gadsby, J.E., Yuh, K-C.M. \& Bill, II, C.H. (1983) The corpus luteum. In International Review of Physiology, Vol. 27, pp. 57-97. Ed. R. O. Greep. University Park Press, Baltimore.

Knickerbocker, J.J., Wiltbank, M.C. \& Niswender, G.D. (1988) Mechanisms of luteolysis in domestic livestock. Domestic Animal Endocrinology 5, 91-107.

Lei, Z.M., Chegini, N. \& Rao, Ch.V. (1991) Quantitative cell composition of human and bovine corpora lutea from various reproductive states. Biology of Reproduction 44, 1148-1156.

Lobel, S.A. \& Knight, K.L. (1984) The role of Ia molecules in immune functions as determined with the use of an anti-Ia monoclonal antibody. Immunology 51, 35-43.

Pate, J.L. \& Nephew, K.P. (1988) Effects of in vivo and in vitro administration of prostaglandin $F_{2 *}$ on lipoprotein utilization in cultured bovine luteal cells. Biology of Reproduction 38, 568-576.

Snyder, D.S. \& Unanue, E.R. (1982) Corticosteroids inhibit murine macrophage Ia expression and interleukin I production. Journal of Immunology 129, 1803-1805.

Terada, Y. \& Ueno, A. (1984) A microangiographic study of renal allograft rejection and the effects of 
immunosuppression in the rabbit. Transplantation $37,443-446$.

Tomasgard, G. (1976) Plasma progesterone in heifers treated with prednisolone during the oestrous cycle. Nordisk Veterinar Medicin 28, 505-510.

Tsukada, T., Rosenfeld, M., Ross, R. \& Gown, A.M. (1986) Immunocytochemical analysis of cellular components in atherosclerotic lesions: use of monoclonal antibodies with the Watanabe and fat-fed rabbit. Arteriosclerosis 6, 601-613.

Wang, F., Preston, S.L. \& Behrman, H.R. (1991) Immunosuppressive glucocorticoid blocks luteal regression in the pseudopregnant rat. Biology of Reproduction 44, 110, Abstract 230.

Wilkinson, J.M., Wetterskog, D.L., Sogn, J.A. \& Kindt, T.J. (1984) Cell surface glycoproteins of rabbit lymphocytes: characterization with monoclonal antibodies. Molecular Immunology 21, 95-103.

Wiltbank, M.C., Diskin, M.G., Flores, J.A. \& Niswender, G.D. (1990) Regulation of the corpus luteum by protein kinase C. II. Inhibition of lipoprotein-stimulated steroidogenesis by prostaglandin $\mathrm{F}_{2 \alpha}$. Biology of Reproduction 42, 239-245.

Received 23 September 1991 